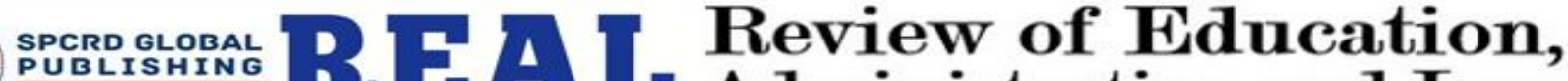 Administration and Law \\ Journal homepage: http://real.spcrd.org ISSN (Print): 2708-1788

\section{Postmodernity in Elif Shafak's “The Forty Rules of Love”}

${ }^{\text {a Nabila Akbar, }}$ Marium Majeed, c Izza Bilal Karori, d Aamir Aziz

${ }^{a}$ Lecturer, Department of English, University of Sahiwal, Pakistan

Email: nabilaakbar@uosahiwal.edu.pk

${ }^{\mathrm{b}}$ Associate Lecturer, The Islamia University of Bahawalpur, Rahim Yar Khan Campus, Rahim Yar Khan, Pakistan Email: mariummajeed13@gmail.com

c Secondary School Educator, Govt. Girls Elementary School, Bhawanpur Shumali, Pakistan Email: izzabilal92@gmail.com

d Lecturer, Department of English, University of Sahiwal, Pakistan

Email: aamiraziz@uosahiwal.edu.pk

\begin{tabular}{|c|c|}
\hline ARTICLE DETAILS & ABSTRACT \\
\hline $\begin{array}{l}\text { History: } \\
\text { Accepted } 19 \text { Nov } 2020 \\
\text { Available Online } 31 \text { Dec } 2020\end{array}$ & $\begin{array}{l}\text { As the term indicates, postmodernity or postmodern condition refers to } \\
\text { social, cultural or economic conditions that emerged in western society } \\
\text { after modern age. It can safely be considered as counterpart of modern } \\
\text { outlook. This research venture has been undertaken to divulge }\end{array}$ \\
\hline $\begin{array}{l}\text { Keywords: } \\
\text { Postmodernity, Postmodern } \\
\text { Literature, Pop Culture, } \\
\text { Technology, Society }\end{array}$ & $\begin{array}{l}\text { postmodernity in prevailing social structure through "The Forty Rules of } \\
\text { Love" by Elif Shafak. This novel has been scrutinized deeper keeping in } \\
\text { view postmodernity. The results unlock depiction of the pop culture, } \\
\text { hypocrisy, dual standards, quest for meaning and purpose in life, social } \\
\text { follies and wavering personalities by the author. This research paper }\end{array}$ \\
\hline $\begin{array}{l}\text { JEL Classification: } \\
\text { I2O }\end{array}$ & $\begin{array}{l}\text { winds up that the author has, by highlighting postmodern elements in } \\
\text { the novel, revealed societal and cultural issues prevailing in present } \\
\text { times. }\end{array}$ \\
\hline DOI: $10.47067 /$ real.v3i3.88 & $\begin{array}{l}\text { (C) } 2020 \text { The authors. Published by SPCRD Global Publishing. This is an } \\
\text { open access article under the Creative Commons Attribution- } \\
\text { NonCommercial } 4.0\end{array}$ \\
\hline
\end{tabular}

Corresponding author's email address: nabilaakbar@uosahiwal.edu.pk

\section{Introduction}

In Sarup's view Modernism is the culture of modernity while Postmodernism is the culture of postmodernity (Sarup, 1993). Through social, economic, cultural structure and mindset of the people in western world, Postmodernity followed modernity in 1980s and 1990s. Jameson opines that modernity died after World War II (Jameson, 1991). Any response or circumstances that pave the way to a postmodern society can safely be called postmodernity. Both 'Postmodernism' as well as 'Postmodernity' are the terms which results in ambiguity. Opting of postmodern features in society, culture, literature and art is Postmodernism while a postmodern society is called postmodernity (Nilges, 2015).

Salient feature of postmodernity is the rise of pop culture in 1960 s and 1970s with the excessive use of pop styles of drama and music and abundant use of marijuana and psychedelics. Modernity 
came forth as result of industrialization while postmodernity popped up as the result of massive use of mass media and telecommunication. Postmodernity disillusioned the people of "Utopian World" and presented a view of the world that is ugly, threatening, harsh, heinous and arbitrary. Postmodern society brought forward a dystopian world.

Elif Shafak is a Turkish author. She has written The Forty Rules of Love in 2010 which was the best-selling novel in Turkey. It consists of two parallel narratives. The first narrative depicts story of a Jewish woman named Ella. She is a house-wife bound in a troubled marriage. Her life revolves around her husband and three kids but still she feels emptiness in her life. Ella's job is in a literary agency and she has been assigned to write a report on a book "Sweet Blasphemy". The second narrative of Shafak's novel is story of the book named "Sweet Blasphemy". This book narrates story of a dervish named Shams of Tabriz who saw dreams about his demise and quests for a fellow to whom he could transmit his insight. Shams later find a friend named Rumi. Ella moved by "Sweet Blasphemy" attempts to find Aziz Zahara (writer of the book). After this, both of them bonds with each other over e-mail and Ella figures out the fact that she is in love with Aziz.

This study will respond to the following queries:

- Can the society depicted in The Forty Rules of Love be considered a postmodern society?

- Can the society depicted in The Forty Rules of Love be considered a reflection of our contemporary society?

Significance of this research lies in the matter that the novel depicts a society that is postmodern. This research will also investigate how the societies portrayed in The Forty Rules of Love are a reflection of our present-day society by explaining how postmodernism is delineated in literature by the writers. It will also explain how the ideas or concepts incorporated in literature foster obvious impact on the mentality of people and it can also contribute greatly in molding their ideologies.

\section{Literature Review}

Struggle of the people for survival in a society of dual standards and hypocrisy is the feature of postmodern culture. The Scarlet Letter (1850) by Hawthorne is the true depiction of postmodernity though it is considered a classic. It can easily be considered as illustration of today's society that has different standards of chastity and purity for different people. The protagonist in the novel, Hester, proves her innocence in front of the people who are not angelic themselves. "If truth were everywhere to be shown, a scarlet letter would blaze forth on many a bosom besides Hester" (Hawthorne, 1850: 72). Venomous society had infused considerable amount of malice and hatred among its masses that even children used to hate and scorn Hester as well as her daughter Pearl.

In The Handmaid's tale (1985), Atwood elucidates a society from the viewpoint of a handmaid, Offred. This is a sci-fi, speculative and dystopian novel in which people are callous, unscrupulous and careless about what is happening around them.

"You can't make an omelet without breaking eggs, is what he says. We thought we could do better. Better? I say, in a small voice. How can he think this is better? Better never means better for everyone, he says. It always means worse, for some" (Atwood, 1985: 211).

People's perception and consciousness is highly affected by the use of mass media which includes television, radio, computer, internet, cellular phones, film and music. This mass media further 
influences the production of postmodern literature. In Generation X (1991), Coupland portrays a generation having significant comprehension and expertise regarding technology as they grew during the era of Computer. Three members of this generation $\mathrm{X}$ move from a commercialized society to another part in order to rediscover themselves. This novel has been written in first person narrative because every member tells his/her own story from a subjective point of view incorporating financial, legal, filial, mental and medical issues. This novel deals with modern day's issues of American dream, class consciousness, materialism, technology, alcoholism, frustration and drug addiction.

"You see, when you're middle class, you have to live with the fact that history will ignore you. You have to live with the fact that history can never champion your causes and that history will never feel sorry for you.” (Coupland, 1991: 147).

According to Shah (2020), Tillie Olsen's I Stand Here Ironing is about stereotypical gender roles of society from a social constructed feminist viewpoint and it illustrates that the society is only concerned about establishing a public patriarchy for women and keep reminding them about their traditional gender roles.

Wake (2013) threw light upon Baudrillard's use of the term "Hyperreality" which is very much associated with postmodern culture and society that is vulnerable to television and electronic media. This media creates an image or perception in minds of the audience. This image is far different from the reality and the people are unable to see the gap between the things presented and the reality.

According to Mendible (1999), popular culture is the main subject of academic postmodernism. He opines that cultural productions like pornography, B-movies, soap-operas, working class literature and pulp fictions are entities to be surveyed by the theorists of popular culture. He considers it abomination of Postmodernism. Postmodernism is actually going back in theory where cornered and alienated elements in literature and art become 'center' in western epistemology and 'high' theoretical discourse takes within it the 'low' (vulgar and popular) elements and throw it in limelight. He further says that 'third world's countries' of the world seem to be challenging the power status of 'first world' countries through its food, culture, literature, movies and art.

Flisfeder in Postmodern Theory and Blade Runner (2017) explains history as well as features of postmodern theory and criticism and also applies those features to Ridley Scott's film Blade Runner (1982). Flisfeder presents how the film's postmodern and marxist analysis provide insights for comprehending our contemporary society, politics and culture. He talks about cyberpunk, hyperreal setting, parody, pastiche and other postmodern elements in the movie (Elrod: 2019).

\section{Research Methodology}

The Forty Rules of Love (2010) written by Elif Shafak has been analyzed from the aspect of postmodernity or postmodern society. It is a qualitative research. Data taken for this research venture will be discussed and analyzed from some postmodern elements presented by Jean Baudrillard in For a critique of the Political economy of a Sign (1981), Linda Hutcheon's identified elements of postmodernism in The Politics of Postmodernism (1989) and postmodern elements discussed by Jameson in Postmodernism, or, The Cultural Logic of Late Capitalism (1991).

\subsection{Analysis}

Elements of postmodernist society include media culture and capitalism (Baudrillard: 1981). 
Hutcheon (1989) views domination of capitalism, photography, music, dance and films as parts of postmodernism. Jameson (1991) strongly agrees that drugs and its culture are vital part of postmodernism. All these aspects are mentioned in the novel under study.

Suleiman is depicted as a drunken in the novel. In order to satisfy his need he used to visit tavern. He is of the view that not drink but people who commit crimes after drinking are faulty. Ella was informed by Aziz that he used to take drugs after his wife (Margot)'s death. He used variety of drugs such as heroin, marijuana, hashish and hemlock. In Morocco, where Aziz was living with few Sufis, he was informed by their leader that drug intake is prohibited here. Aziz concluded that his luggage has been checked by them but the Master stated:

"We don't need to look through your belongings to know you are using drugs, Brother Craig. You have the eyes of an addict” (232).

Ella's story is the best example of pop culture. The Rubinsteins had a lavish lifestyle. They had a large Victorian house in Northampton. In their house there were five bedrooms, shiny hardwood floors, French doors, three bathrooms, a garage in which three cars could be parked and decent furniture. They also owned two apartments: one in Boston and other in an island named Rhode. Besides, they had the luxury of joint bank accounts. They had car insurances, life insurances and plans related to retirement. Apart from the job of David, Ella used to work in literary agency; her work included editing small scripts for women's magazines. Ella used to compose book reviews for some papers as well.

This novel put light on the problems related to unemployment as well as the need for having more than one job because of certain financial pressures. Vacancies are less and people who want to apply for those seats are more in number. At one point in the novel, Ella was reluctant to analyze a Sufi novel. Michelle wanted to motivate her for the report. She said to Ella that many young people want to apply for the job Ella has. The novel highlights the fact that those who are beneficial have more regard. For example, Aziz (the new writer)'s work was assigned to a new assistant as he was not an acclaimed writer. Steve passed novel of Aziz to Michelle who handed it over to Ella.

Expensive restaurants and scrumptious food items are mentioned in the novel which portrays pop culture. In the novel under discussion, Samarkand in the year 1242 is depicted with a vast range of food. Dishes of an inn consisted of "freshly grilled goat, dried salted fish, spiced mutton, wheat cakes, chickpeas with meatballs, and lentil soup with sheep's-tail fat” (29). In menu of Ella there were various dishes as well, present on daily basis. Such as:

"Clam Chowder with Saffron, Coconut and Oranges

Pasta Baked with Mushrooms, Fresh Herbs, and Five Cheeses

Rosemary-Infused Veal Spareribs with Vinegar and Roasted Garlic

Lime-Bathed Green Bean and Cauliflower Salad" (61).

"Warm Chocolate Souffle" was in the menu as a form dessert.

Cosmetics and dieting are also the part of Pop culture. Ella craved for ice-cream but did not eat it because it would result in gaining her weight that's why "she took a step away from the fridge and slammed the door, ...” (54) as she was on dieting. Calvin Klein's Perfume Eternity was used by her. Her resolution list (doing 10 things to do before turning 40) included buying new cushions, purchasing new plants and to apply New L`Or`eal cream. 
Pop culture has led humans in spending busy and on the go lives. It has forced them for getting involved in multitasking. Michelle used to work for multi projects at a time. She was an active housewife. She could check emails, read different reviews, eat sandwich, apply nail-polish and talk on phone at a time.

Ella was curious about the person (writer) she was asked to write a report on. That's why, she googled A.Z. Zahra. She learnt via Google that A.Z. Zahra considers himself a Sufi and he is also a professional photographer who is going to Guatemala. His pictures depict incompleteness in life. Ella was also able to get his email via net.

Apart from pictures, internet and phone, the technology focused in the novel is TV. Ella was once watching TV in the novel. She was watching different tragic news and felt that the fear of these news has spread in the whole world. Ella and Aziz sent and received each other's photographs via mail. They called each other on phone as well. At one point in the novel, children of Ella were discussing DVD of Pirates of Caribbean. Ella was of the view, "Cyberspace both magnified and mellowed offline behaviors, providing an opportunity to flirt without guilt... and an adventure with our risks...” (143).

Struggle for survival of those living in hypocritical society is focused in postmodern society. Societies of two different time periods are depicted in Elif Shafak's novel under study. Ella's narrative is set in Northampton (2008-2009) while the setting of Shams and Rumi's narrative is Konya (12421248). While writing introduction of his book, Aziz says, "In many ways the twenty-first century is not that different from the thirteenth century. Both will be recorded in history as times of unprecedented religious clashes, cultural misunderstandings, and a general sense of insecurity and fear of the Other...” (15).

As far as the plot of Shams and Rumi is concerned, killer was informed by the people that dervish (Shams) does not follow Islam. However, he was paid thrice of the actual price by people so that he can murder Shams. At that time, they did not pay heed to the fact that killing is forbidden in their religion (Islam).

"He is a heretic who has nothing to do with Islam. An unruly man full of sacrilege and blasphemy. A maverick of a dervish" (24).

A universal fact is that truth hurts and truth also tastes bitter. People usually try to avoid truth as it focuses on the harsh realities. One such incident occurred when innkeeper asked Shams to read his palm and in return he would be provided by the food. But when Shams told innkeeper about his future after reading his palm, innkeeper asked him to leave in the morning as he do not want to see his face anymore. "It was always like this. When you spoke the truth, they hated you. The more you talked about love, the more they hated you” (33). In Shams' view, it is hypocrisy which makes humans merry and they become unhappy by knowing truth.

People generally watch over those who are advantageous and do not care for the lot belonging to lower class. Such as in the dervish lodge of Baghdad, the novice was working from day to night but no one was bothered for him, no one was interested in learning his actual name. Everyone used to call him "The New Novice". People were much bitter behind his back. He was being mentioned as "gingerhaired ignoramus" when he was not around. He used to do many strenuous tasks such as mopping the floors, sweeping the courtyard, baking the bread, bringing water from the creek etc. Once Shams said sorry to a peasant after acknowledging the fact that Shams was wrong. The peasant was flabbergasted 
by that apology. He told Shams that until now no one has bothered to say sorry to him after doing wrong. Give and take is considered normal in the society. In the novel, Sesame kept Desert Rose's secret of attending Rumi's sermon because she bribed him by giving 'Halva'.

It is a general norm that people surrounding us cannot not discuss us, it is impossible for one person to make everyone happy. Generally, the person who is lonely at the end of the day is the one who focuses on the fact that what others are going to think about him/her. Same thing happened when novice was offered wine by Shams but he refused. In response to this, Shams stated, "You are too timid for me. You care too much about what other people think. But you know what? Because you are so desperate to win the approval of others, you'll never get rid of their criticisms, no matter how hard you try" (89). Another incident related to the ongoing topic occurred when Shams informed Kerra that Desert Rose will live in their house with them. Kerra became quite conscious that what people will think. She argued, "But what will our neighbors say if they learn we have a girl of ill-repute under our roof?” (266). Similarly, Irshad (companion of Aladin) said to Aladin that Shams is causing wrong impact on his father so it's better for Aladdin to purify his family's name. At another point in the novel, during the wedding night Shams was about to leave the room but Kimya asked him not to do so because if this happened then society will not consider her a virgin.

Even those who were dead warned Shams about harsh society of Konya. Shams reached Konya and paid respects to all the saints (living, dead, known and hidden). The saints responded to him through wind, "O dervish, in this city you'll find only two extremes, and nothing in between. Either pure love or pure hatred. We are warning you. Enter at your own risk” (100).

In almost every corner of the earth, poverty is present. The writer has focused on this problem with the help of Hassan the Beggar's character. Mothers used to point at him in order to make their children scare, many small kids throw stone at him, pregnant women tried not to look at him and turn away so that their babies would born healthy and without any defect. But according to society, God answers the lepers' prayers. "Whenever I am hired to pray, I bow my head and make incomprehensible sounds in Arabic, pretending to be absorbed in prayer" (105).

"Though it is less profitable, I find begging much easier than praying. At least I am not deceiving anyone" (105).

Poverty gives birth to many crimes. According to Hasan, when Rumi gave his sermon, that day was a profitable day for pickpockets and beggars because many people were present in the mosque at that time. It depicts that people do not bother the sermon. He is of the view that a leper does not need to make a story of thousand words. In fact, to uncover his face was enough for him. People do not make eye contact with him as "if my (his) gaze were contagious" (106). People only see what he was lacking and do not ponder upon what he had. They were scared of him as what they see in him was 'death'. During the sermon, mosque was jam-packed but people avoided sitting with him (a leper). Hasan left the mosque in dismay as Rumi was giving sermon on suffering and according to Hasan, Rumi knew nothing regarding suffering because he never had faced it himself.

Prostitution is also present in almost every society. The women belonging to those places are considered morally polluted and corrupt. In many people's view, women who belong to this profession are in it by their own choice. Hermaphrodite told Shams that standing in a brothel is not suitable for him. He further said that people consider him a sinful person but he also gives alms and doors of brothel are not opened during Ramadan. He informed Shams that he is protecting him from the dirtiest area of this town. 
Even if a person tries to change, people do not forget the past of that person. Desert Rose is of the view that people hate harlots but if a harlot wants to change herself according to the standards of society, people make sure that this does not happen as well. Desert's mother died in labor, giving birth to triplets (three sons). Only one son survived and others died. Her father used to mistreat her brother because of this reason. Later, her step-mother ill-treated her brother too. One day both parents were found dead because they were poisoned by 'rat killing medicine'. Her brother left home post that incident. Desert Rose was raped by robbers when she was going towards Constantinople to meet her aunt. After sometime, she ran from their clutches. Jackal Head gave Desert Rose to a brothel in Konya. Even then, no one bothered to look for the reason of her presence in brothel. At one point in the novel, Desert Rose dressed up in men's clothing went to the mosque in order to attend Rumi's sermon. People were unable to bear a harlot in mosque. They shouted, "Lash the deceiver! Lash the whore!" (123). Baybars reacted, "This woman here dressed up as a man and sneaked into the mosque to deceive good Muslims" (124). Someone else's voice came, "She is a whore!" ... "She has no place in a holy mosque!" (124). Those people were snubbed by Shams as he said, “...If you were the good believers you claim to be, you would not have noticed this woman even if she were naked..." (125). Desert felt dejected and hurt because of people's behavior. She said to Shams that a harlot is not welcomed in any house of God (church or mosque). Baybars, after this incidence, came to brothel in order to have intercourse with Desert Rose. During that sex he beat her hard. One of Rose's customers used to spit on prostitutes while having intercourse and was in the habit of calling them "Dirty".

Sheikh Yassin made comments on Rumi's wife. He said that since she is from Christian background so she will remain Christian. It does not matter whether she converted. Since, she was a Christian during her childhood, so Christianity will remain in her blood. He further gave a remark about the blood of his child, "Can water and oil ever mix? That is the extent to which Muslims and Christians can!” (253). So, according to Sheikh Yassin's viewpoint those individuals who convert from other religions into Islam can never be Muslims because of their previous religion and past. Shams, in the class of Sheikh Yassin, informed his pupils that The Sufi suggested that one should look for his/her own inner encounter with God. He further stated that one should not indulge in the habit of judging others. A scholar having orthodox behavior would look for others' flaws whereas "...most of the time he who complains about others is himself at fault" (259).

Once Suleiman told Hristos that individuals who are more religious, think that others are inferior from them and they are confident that God is with them. Baybars (who became religious and was a security guard) used to go to brothel for visiting prostitutes. He himself beat Desert Rose and beat Suleiman to stop him from drinking alcohol. Ambivalence in his personality can be depicted from the point that he considered himself a good Muslim but used to visit brothel and objected on the instance when Hazrat Ali (R.A.) did not kill an infidel.

People were in habit of pointing out that Rumi has been easily manipulated by the hands of Dervish (Shams), who does black magic and every morning asks Rumi to drink the soup made up from snake. Shams was of the view that people never try to stay away from badmouthing. In society those people who drink wine or are in habit of having extra-marital affairs are considered sinful. However, society never points out at those who are in the habit of badmouthing. In reality, badmouthing is a graver sin as compared to drinking wine or committing adultery.

Balance is created in the society when people do good with those who do good with them. When Shams left Konya, Walad was informed by leper about many people who were aided by Shams. They used to love Shams because of his help. After hearing the plot of Shams's murder, Suleiman went to 
various places to find Shams in order to warn him beforehand.

Shafak depicts men as hypocrites in Ella's story. David said to Ella that she will be forgiven by him for having an affair with Aziz. But he did not pay heed to the point that he also had multiple affairs. He did not say sorry to Ella for his affairs. After some events, when Ella was ready to go with Aziz (who was suffering from cancer), her friends considered her a foolish person who is ready to sacrifice her future because of her present feelings. Ella realized, “...if there was anything worse in the eyes of society than a woman abandoning her husband for another man, it was a woman abandoning her future for the present moment" (346). Hence, in this novel, apart from hypocrisy, other flaws of that time are also mentioned which can be seen even today in our society.

\section{Conclusion}

The novel depicts pop culture as well as hypocrisy of society with the help of events which shows dual standards of people, hypocrite characters and wavering personalities. The novel also depicts bitter realities and darker side of society. It focuses on the issues related to religious hypocrisy, dilemma of poor, ill-treatment with lepers, robbery, prostitution, bad-mouthing and gossiping. Thus, the novel The Forty Rules of Love manifests postmodern elements in such a way that it also reflects the hypocrisy of portrayed society that is almost identical to our contemporary society. So, we can easily conclude that the societies (Northampton, Samarkand, Alexandria, Konya and Baghdad) depicted in The Forty Rules of Love are postmodern and can be considered a reflection of our present-day society. The social issues depicted in the novel can produce an evident influence on the mentality of people by showing how a society can be ruined by unfollowing social values. By reading such literature people can try to correct their faults and can contribute to a great extent in shaping their ideologies.

\section{References}

Atwood, M. (1985). The Handmaid's Tale. McClelland and Steward.

Baudrillard, J. (1981). For a Critique of the Political Economy of the Sign. Trans. Charles Levin New York.

Coupland, D. (1991). Generation X. St. Martin’s Press.

Elrod, James M. (2019). Postmodern Theory and Blade Runner. Science Fiction Film and Television, 12 (3), 394-397.

Flisfeder, M. (2017). Postmodern Theory and Blade Runner. New York: Bloomsbury Publishing.

Hawthorne, N. (1850). The Scarlet Letter. Ticknor, Reed and Fields.

Hutcheon, L. (1989). The Politics of Postmodernism. Routledge.

Jameson, F. (1991). Postmodernism, or, The Cultural Logic of Late Capitalism. Durham, NC: Duke University Press.

Mendible, M. (1999). High Theory/low Culture: Postmodernism and the Politics of Carnival. Journal of American Culture (Malden, MA), 22 (2), 71-76.

Nilges, M. (2015). The Presence of Postmodernism in Contemporary American Literature. American Literary History. Advance Access Publication, 27 (1), 186-197.

Olsen, T. (1961). Tell me a riddle. London: Virago.

Sarup, M. (1993). An Introductory Guide to Post-Structuralism and Postmodernism. Athens: The University of Georgia Press.

Shafak, E. (2010). The Forty Rules of Love. Viking Penguin, Printer.

Shah, M. (2020). Stereotyping of Gender Roles and Norms by Society: a Feminist Analysis of I Stand Here Ironing. Review of Education, Administration and Law (REAL), 3 (2), pp. 149-156.

Wake, M. (2013). The Routledge Companion to Critical and Cultural Theory. Routledge. 